Finance and Economics Discussion Series Divisions of Research \& Statistics and Monetary Affairs Federal Reserve Board, Washington, D.C.

\title{
The Liquidity Effect in the Federal Funds Market: Evidence from Daily Open Market Operations
}

\section{Seth Carpenter and Selva Demiralp}

2004-61

NOTE: Staff working papers in the Finance and Economics Discussion Series (FEDS) are preliminary materials circulated to stimulate discussion and critical comment. The analysis and conclusions set forth are those of the authors and do not indicate concurrence by other members of the research staff or the Board of Governors.

References in publications to the Finance and Economics Discussion Series (other than acknowledgement) should be cleared with the author(s) to protect the tentative character of these papers. 
The Liquidity Effect in the Federal Funds Market:

Evidence from Daily Open Market Operations

Seth Carpenter and Selva Demiralp

Division of Monetary Affairs

The Board of Governors of the Federal Reserve System

September 2004

\begin{abstract}
We use forecast errors made by the Federal Reserve while preparing open market operations to identify a liquidity effect at a daily frequency in the federal funds market. Unlike Hamilton (1997), we find a liquidity effect on many days of the reserve maintenance period besides settlement day. The effect is non-linear; large changes in supply have a measurable effect but small changes do not. In addition, a higher aggregate level of reserve balances in the banking system is associated with a smaller liquidity effect during the maintenance period but a larger liquidity effect on the last days of the period.
\end{abstract}

The views expressed are those of the authors and do not necessarily reflect those of the Board of Governors, the Federal Reserve System, or other members of the staff. We thank Heather Wiggins and Shawn Liu for research assistance. We also thank Dennis Farley, Sherry Edwards, and seminar participants in the Division of Monetary Affairs, and staff at the Domestic Money Market Desk at the Federal Reserve Bank of New York for helpful comments. Carpenter: Mail Stop 60, $20^{\text {th }}$ and C Street, NW Washington, DC 20551 scarpenter@frb.gov, Demiralp: Mail Stop 59, $20^{\text {th }}$ and C Street, NW Washington, DC 20551 selva.demiralp@frb.gov 


\section{Introduction}

The ability of the Federal Reserve to control the federal funds rate is taken for granted. Each morning, the trading desk (the Desk) at the Federal Reserve Bank of New York (FRB-NY) conducts open market operations to adjust the supply of reserves in the banking system in order to achieve the target for the funds rate set by the FOMC. This manipulation of reserves to affect the funds rate relies on a presumption of a liquidity effect. Specifically, it is assumed that a greater supply of reserves will tend to cause the funds rate to fall ceteris paribus, and likewise, a reduction in the supply of reserves will tend to cause the funds rate to rise.

Hamilton (1997) tested whether this relationship exists at the daily frequency. His results suggest that a significant liquidity effect exists at the daily level only on "settlement Wednesday." That is to say, on the last day of the bi-weekly periods over which banks must satisfy their reserve requirements. In a reinterpretation of Hamilton's work, Thornton (2001) suggests that the evidence is questionable. He argues that Hamilton's results rely primarily on a small number of observations with large movements in the funds rate. Excluding these observations, Thornton does not find evidence of a daily frequency liquidity effect. Previous researchers (e.g. Reichenstein (1987), Leeper and Gordon (1992), Strongin (1995)), analyzing lower frequency data, have noted a similar lack of correlation between monetary aggregates and various interest rates, calling this the "liquidity puzzle."

In this paper, we present strong empirical support for a daily liquidity effect. Moreover, we find evidence of the liquidity effect on several days within the maintenance period, not simply on settlement Wednesdays. Building on these results, we examine some determinants of the magnitude of the liquidity effect. We find that appropriately 
defined "small" exogenous changes in the supply of reserves do not have a statistically significant effect on the funds rate whereas "large" changes in reserves do, suggesting a non-linearity in the liquidity effect. Next, we ask what effect the aggregate level of reserve balances in the system has on the liquidity effect. We find evidence that higher levels of reserve balances lead to an attenuated liquidity effect in the middle of the maintenance period, but a stronger liquidity effect at the end of the maintenance period.

The supply of Fed balances is determined by the Desk's open market operations, discount window lending, and the movements in autonomous factors on the Fed's balance sheet. Autonomous factors consist of Federal Reserve assets and liabilities over which the Desk has little or no control. Hamilton used errors in forecasts of one of these autonomous factors, the Treasury's balance at the Federal Reserve, to identify exogenous shifts in the supply of reserves. While in principle this approach is valid, the forecasts are made from historical data, and thus do not necessarily correspond to actual daily exogenous changes in reserves. Hamilton would like to have an unbiased estimate of the level of reserves in the banking sector that is consistent with the funds rate at the target rate and estimate the effect on the funds rate when the realized value deviates. However, he has one imperfect measure of only one factor affecting the supply of reserves in the market. We propose a more accurate and more complete measure.

Each morning, staff at the Federal Reserve Bank of New York and the Board of Governors make a forecast of all of the factors that affect the supply of reserves in the market. Conditional on these forecasts, the Desk performs an open market operation to equate the supply of reserves with the quantity of reserves that would be demanded that day at the target funds rate. In other words, there is an implicit model of a negatively 
sloped demand curve and a vertical supply curve, with supply adjusted to achieve equilibrium at the target rate.

In evaluating the daily demand for reserves, the Desk considers various factors such as the day of the maintenance period, days when payment-related flows are likely to be elevated, etc. (see Demiralp and Farley (2004) for a detailed discussion of the determinants of daily open market operations). This implies that the quantity of reserves supplied to the market is shifted to account for daily changes in the demand for reserves. When there is a mismatch between the Desk's forecast of the supply of reserves and the actual supply of reserves that is realized in the banking system, the difference—or forecast miss - is an exogenous shift in the supply of reserves. We use the daily forecast miss to identify exogenous shifts in the supply of reserves. ${ }^{1}$ Because the Desk achieves the target rate on average, the correlation between the daily forecast miss and the deviation of the funds rate from the target allows us to estimate the liquidity effect at the daily frequency.

Under our identification scheme, we estimate a statistically significant negative relationship between changes in the supply of reserves and the federal funds rate. We find that many, but not all, days within a maintenance period exhibit a liquidity effect. Echoing Hamilton's findings, the effect is particularly strong on settlement Wednesday. We believe our measure is superior to Hamilton's measure in that it is not based on an estimate of a reserves miss, but is the reserves miss itself. Moreover, we find that the results are statistically significant after 1994 when the Federal Reserve began announcing changes to the target rate. It has been speculated, for example by Thornton (2001) that

\footnotetext{
${ }^{1}$ More specifically, we take the Board staff forecast to calculate the miss. As a robustness check, we also use the forecast miss from the FRB-NY and the average of the two. The results are essentially the same.
} 
following the announcement of the target, manipulation of reserves was no longer needed to maintain the funds rate target and thus there ought not be a liquidity effect. In contrast, we find that the liquidity effect is evident in the post-1994 sample. In fact, if there is a downward sloping demand curve for reserves, so-called "open mouth operations" would only be able to change the funds rate to the new target by shifting the demand curve through expectations of a different future rate, while a manipulation of reserves would still be required to maintain the target. In this respect, our results are not inconsistent with the view that announcement effects are important in the daily market.

The following section lays out an overview of the literature on the liquidity effect, putting the current work into context. The next section explores the federal funds market in some detail and explains the institutional characteristics that allow us to identify shifts in the supply of reserves. Next, we present our empirical specification and our results. The final section concludes, drawing comparisons between the current work and previous work, as well as the results from a related paper on the liquidity effect at the monthly frequency.

\section{The Liquidity Effect and the so-called Liquidity Puzzle}

Generally speaking, the liquidity effect is a negative relationship between a measure of money and an interest rate. The economics literature has no shortage of papers that investigate this type of relationship, including e.g. Cochrane (1989), Gali (1992), Leeper and Gordon (1992), Strongin (1995), Pagan and Robertson (1995), Christiano (1991), Bernanke and Mihov (1998), Hamilton (1997), and Thornton (2001). The methodologies and the results are mixed; some researchers have not found a consistent relationship — the "liquidity puzzle"—while other researchers have. 
At the heart of all the analysis is a demand curve for some type of money that in principle depends negatively on an interest rate. The liquidity effect, then, can be thought of as directly related to the slope of this demand curve. Leeper and Gordon (1992), Pagan and Robertson (1995), and others have used a monetary aggregate (M1 or M2) and an open market interest rate (such as the yield on the three-month Treasury bill) to test for the liquidity effect. The fact that results are not robust in this setting is taken to be a lack of evidence for a liquidity effect. However, money demand models for the aggregates are notoriously unstable. Furthermore, changes in broad monetary aggregates are likely to suffer from an endogeneity problem where they embody policy accommodation of demand in addition to exogenous shifts in demand. As a result, failure to estimate a liquidity effect could simply be a misspecification or a shifting of an underlying demand function.

Strongin (1995), Bernanke and Mihov (1998) and others specifically interested in the transmission mechanism explicitly model the federal funds market to estimate a liquidity effect. In particular, Strongin notes that the failure of other researchers to find a liquidity effect can be traced, at least in part, to a failure to account for the Federal Reserve's accommodation of shifts in the demand for money or reserves. Bernanke and Mihov point out that testing for a liquidity effect with monetary aggregates is inappropriate for similar reasons. Explicitly modeling the market of nonborrowed reserves, these researchers find a significant liquidity effect at the monthly frequency.

This set of results is closely linked to results in Carpenter and Demiralp (2004) who also find strong evidence of a liquidity effect at the monthly frequency. That study, however, also highlights the importance of understanding why a liquidity effect may not be present. They note that, looking at contemporaneous correlations, there is a liquidity 
effect with respect to total reserve balances and the federal funds rate. This relationship however, does not hold when only nonborrowed reserves are studied. Because reserve requirements are determined by a bank's customers' demand for reservable deposits, which may or may not depend on the funds rate in a simple way, there is no reason to expect a liquidity effect between nonborrowed reserves and the funds rate in periods when required reserve balances constitute the majority of banks reserve balances.

In his influential work, Hamilton (1997) presents an empirical model of the funds market at the daily frequency and attempts to estimate a liquidity effect. The Treasury maintains an account with the Federal Reserve and each day funds are transferred in and out of this account. As funds are transferred in, they are drained from the banking sector, and thus the federal funds market. Hamilton exploits this relationship and estimates a forecasting equation for the Treasury's Fed account. If this forecasting equation is unbiased, then deviations from the forecast ought to, on average, represent exogenous shifts in the supply of reserves, allowing him to identify the liquidity effect. Hamilton's results suggest that there is a liquidity effect at the daily frequency, however the effect is only statistically significant on the last two days of a maintenance period. Moreover, the point estimate for the penultimate day of the maintenance period is not economically significant. Hamilton's work suggests a liquidity effect, but a very specific one, confined to the last day of a maintenance period.

Thornton (2001) re-examines Hamilton's results and argues that the liquidity effect cannot be identified because it is almost impossible to correctly identify the error that the Fed makes in forecasting the Treasury balance. Moreover, Thornton finds that Hamilton's settlement Wednesday result is "fragile and it arises due to a few settlement 
Wednesdays when there were unusually large changes in the funds rate." Thornton goes on to argue that the liquidity effect can be identified by examining changes in nonborrowed reserves following a change in the target rate. He concludes that the quantities of changes in nonborrowed reserves are relatively small, and thus likely are only signals of a change in target, but not evidence of a liquidity effect itself.

In this paper, we follow these two researchers in examining daily data. In the next section, we explain the daily forecasting and operation procedures of the Federal Reserve and argue that the difference between the actual supply of reserves on a day and the forecast used in determining open market operations provides an exogenous shift in the supply of reserves in the funds market.

\section{The federal funds market and the supply of reserves}

The Desk at FRB-NY conducts open market operations, in an attempt to equalize the demand for and supply of reserve balances in the banking sector at the target federal funds rate. Demand for reserves comes from two primary sources, clearing needs and reserve requirements. Because banks use their Federal Reserve accounts to clear transactions for themselves and their customers, the demand for reserves tends to be higher on days with large expected volumes of payments, such as month-, quarter-, and year-end. In addition, over a two-week maintenance period, banks are required to hold, on average, a quantity of reserves at the Fed proportional to the quantity of transactions deposits at the bank over the previous two-week computation period. Demand for required reserve balances, therefore, can be easily substituted across all fourteen days in a maintenance period, however balances held on a Friday are carried over for both 
Saturday and Sunday. Similarly, starting in 1981 under the Monetary Control Act, banks are able to establish contractual clearing balances with their Federal Reserve Bank, agreeing in advance to maintain a specified level of balances, above and beyond their reserve requirements. In exchange for committing to hold these balances, banks are paid a form of implicit interest on the contractual clearing balances. Specifically, banks are given credits applicable to priced services they receive from their Federal Reserve Bank, and these credits until January 2004 were tied to the funds rate that prevailed over the maintenance period and since then are tied to a fraction of the three-month Treasury bill.

As can be seen in Figure 1, total reserve balances, the sum of required reserve balances, contractual clearing balances, and excess balances, have declined on average over the past decade. This decline is due to several factors including decreases in required reserve ratios and the advent of "sweep accounts" whereby banks move deposits from reservable demand deposits into savings accounts that have a reserve requirement of zero. Because this shift has taken place through time, it is unlikely to have much of an impact on our estimation of the daily frequency liquidity effect.

Excluding contractual clearing balances, reserve balances do not earn any interest. Therefore, banks would like to minimize their holdings of excess reserve balances except to avoid a costly overdraft of their account. For that reason, given the intra-maintenance period substitutability of reserve balances, banks are somewhat hesitant to hold large balances of reserves early in the maintenance period. Figure 2 presents the average pattern of excess reserve balances over a maintenance period from 1989 to present. Banks are often deficient in their reserve requirements early in a maintenance period where their primary objective is to meet their payment-related balances that they must 
hold to avoid overnight overdrafts. They make up the deficiency in the latter part of the period when they have better information about their period-average reserve needs and still satisfy their requirements.

In the context of a simple model, we think of the demand for reserve balances, $d_{t}$, as a function:

$$
d_{t}=\gamma\left(f f_{t}, X_{t}\right)+\varepsilon_{t}
$$

where $f f_{t}$ is the federal funds rate and $X_{t}$ is the set of all other variables that affect demand like the day of the maintenance period or days of heavy transaction flows, and $\varepsilon_{t}$ is a random error term. Note that we do not consider the function to necessarily be linear or separable among these variables.

Each morning, staff at FRB-NY and at the Board of Governors in Washington, D.C. make forecasts of all the factors that affect the supply of reserves. The most important among these factors are currency, check float, and the Treasury's balance at the Fed. Currency is introduced into circulation when banks request a shipment from their Federal Reserve Bank. The value of the currency shipment is then debited from the bank's reserve account. Thus, in times of higher public demand for currency, ceteris paribus, reserves are drained from the system. During the processing of checks, there are occasionally delays in the presentation of checks to banks on which they are drawn. As a result, check float can be created if the receiving bank has been credited before the drawing bank is debited. In this case, reserves in the banking system would be increased until the double counting is undone. Conversely, if the paying institution's account is 
debited faster than the schedule for crediting the receiving institution's account, reserve balances are reduced. As discussed above, the Treasury maintains an account at the Federal Reserve, from which all federal payments are made. When a payment is made out of this account, funds are transferred from the Treasury account into the reserve account of the receiving bank. As a result, payments from the Treasury account increase reserve balances and receipts to the Treasury account drain reserve balances. Note that this effect on reserve balances does not depend on the recipient/payer of the funds. When a private citizen pays his/her taxes, for example, the check used for payment is drawn on a bank. When the check is processed, the bank's reserve account is debited.

With an assessment of the level of demand and a forecast of the factors affecting the supply of reserves, a decision over the size of the needed open market operation for the day is made. On average in our sample, the funds rate is equal to the target rate, therefore we take as a maintained hypothesis that over time the quantity of reserve balances supplied equals the quantity of reserve balances demanded at the target rate. Thus, we also assume that the Desk correctly infers the demand function, an assumption we are able to test below.

The supply of reserve balances on a given day, $s_{t}$, is fixed and equal to the sum of the factors affecting the supply of reserves, $f_{t}$ and the daily open market operation, omo $_{t}$ or:

$$
s_{t}=f_{t}+\text { omo }_{t}
$$


In terms of these simple supply and demand functions, the liquidity effect is essentially a negatively sloping demand curve, or $\partial \gamma / \partial f f_{t}<0$. To attempt to estimate this effect, consider a simplified, linear version of the demand and supply curves.

$$
\begin{gathered}
d_{t}=\alpha X_{t}+\beta f f_{t}+\varepsilon_{t} \\
s_{t}=f_{t}+\text { omo }_{t} \text { where } f_{t}=E_{t-1} f_{t}+\text { miss }_{t}
\end{gathered}
$$

Where $E_{t-1}$ is the expectations operator conditional on an information set as of time $t-1$, and miss $t_{t}$ is the forecast error on day $t$. The intended quantity supplied is adjusted to be equal to the expected quantity demanded, evaluated at the target rate, $f f_{t}^{*}$, subject to the fact that the Fed has only estimates of the parameters of the demand function:

$$
E_{t-1} f_{t}+o m o_{t}=\hat{\alpha} X_{t}+\hat{\beta} f f_{t}^{*}
$$

In equilibrium, supply must equal the demand for reserve balances. Substituting $f_{t}$ into (5) and moving total factors miss to the right hand side:

$$
\hat{\alpha} X_{t}+\hat{\beta} f f_{t}^{*}+\text { miss }_{t}=\alpha X_{t}+\beta f f_{t}+\varepsilon_{t}
$$

Re-arranging (6) we get the following equation:

$$
\left(f f_{t}-f f_{t}^{*}\right)=(\hat{\beta}-\beta / \beta) f f_{t}^{*}+(\hat{\alpha}-\alpha / \beta) X_{t}+(1 / \beta) m i s s_{t}+(1 / \beta) \varepsilon_{t}
$$

This equation merits a few comments and will be the basis for our more general empirical specification elaborated in the next section. First, and foremost, the coefficient on the 
daily forecast miss allows us to test for a daily frequency liquidity effect as it is the reciprocal of the partial derivative of the demand for balances with respect to the funds

rate. Econometrically, this should be a valid test because the forecasts are made by staff at the Federal Reserve about factors affecting the supply of reserves and are not related to random fluctuations in banks demand for reserve balances. Thus, they should be uncorrelated with the error term. The set of variables $X_{t}$ represents the set of variables that shift the demand for reserve balances on a daily basis. If the Desk estimates these daily fluctuations in demand accurately, then the coefficients will be equal to zero, otherwise the dummy variables will soak up these daily disturbances. Lastly, the equation suggests including the target level of the federal funds rate into the specification. This coefficient will provide a test about whether or not, on average, the level of the target generates a systematic bias in the deviations from the target. Further, a statistically significantly negative (positive) coefficient implies that the Desk under- (over-)estimates the slope in the underlying function.

\section{Empirical Specification}

\section{IV-1. Data}

Data on the daily effective funds rate are published in the Federal Reserve's H.15 statistical release. This rate is the weighted-average interest rate paid on overnight funds traded in the brokered federal funds market. Beginning in 1994, the Fed began announcing changes in its target for the federal funds rate. In general, but not always, these changes have occurred at FOMC meetings. The data on daily forecast misses come 
from internal databases maintained at the Board of Governors. We use forecast misses from the Board of Governors.

\section{IV-2. Specification}

While the simple model outlined in the previous section assumed that the demand for reserve balances was strictly linear and separable in the funds rate and other factors that affect demand, we relax that assumption somewhat to be able to test for intramaintenance period variation in the liquidity effect. In addition, we estimate an exponential GARCH specification (Nelson (1991)) for the deviation of the funds rate from the target rate in order to allow for conditional heteroscedasticity in the error term. High payment flow days may shift the demand for funds, but they also instill greater uncertainty in the market and influence daily volatility that we wish to model. The EGARCH specification further allows for asymmetry in volatility as defined by the variance of the error term, $\sigma^{2}$.

$$
\begin{aligned}
& \left(f f_{t}-f f_{t}^{*}\right)=\beta_{1} D_{1}\left(f f_{t-1}-f f_{t-1}^{*}\right)+\beta_{2} D_{2}\left(f f_{t-1}-f f_{t-1}^{*}\right)+\mathrm{A} m p d a y_{t}+\mathrm{Bmpday}_{t} * m_{i s s_{t}}+C X_{t}+\varepsilon_{t} \\
& \log \sigma_{t}^{2}=\omega+\eta\left|\frac{\varepsilon_{t-1}}{\sigma_{t-1}}\right|+\psi \frac{\varepsilon_{t-1}}{\sigma_{t-1}}+\lambda \log \sigma_{t-1}^{2}+\Phi Z_{t}+\omega_{t}
\end{aligned}
$$

Where $D_{i}$ is a dummy variable corresponding to the $i=1,2$ week of the maintenance period. We include the daily forecast error, miss, interacted with dummies corresponding 
to each day of the maintenance period, $m p d a y_{t}$. In addition, we include a set of variables to control for daily shifts in the demand for reserve balances, these are:

- A dummy variable for each day of the maintenance period.

- A dummy variable for month-ends, quarter-ends, and year-ends, respectively.

- A dummy variable for the first day of a month, quarter, and year, respectively.

- A dummy variable for the $15^{\text {th }}$ of a month.

- Dummy variables for the day before and the day after a holiday, respectively.

- An interaction of a dummy for the day before a target change and the anticipated change in the target rate as implied by fed funds futures contracts.

- An interaction of a dummy for the day of a target change and the unanticipated change in the target rate as implied by fed funds futures contracts.

- A dummy variable for the month of December.

- The target for the federal funds rate.

The variance equation has the following variables:

- EGARCH terms.

- A dummy variable if the observation is in the last three days of a maintenance period.

- Dummy variables for the first and the second Fridays of a maintenance period.

- A dummy variable for the day before and after a change in the target rate, respectively.

- A dummy variable for the day before and after a holiday, respectively.

- A dummy variable for month-, quarter, and year-end.

- A dummy variable for the month of December. 


\section{Results}

V-1. Basic results

The results of the estimation are presented in Table 1. The sample period covers May 19, 1989 through June 27, 2003. The starting point of our sample corresponds to the establishment of the Fed funds futures market at Chicago Board of Trade. Columns 2 to 4 present full-sample results. In order to check whether the period after February 1994, display a change in parameters, we also present the results for this latter period in columns 5 to 7 .

A likelihood ratio test of the hypothesis that all of the coefficients of the miss interacted with the days of the maintenance period are zero is rejected at the $1 \%$ confidence level. We consider this negative and statistically significant coefficient to be clear evidence of a liquidity effect at the daily frequency. In examining these coefficients more closely, however, interesting patterns emerge.

Corroborating Hamilton (1998), we find the largest liquidity effect is on settlement Wednesday. Banks must fulfill their reserve requirements by settlement Wednesday; deficiencies cannot be shifted to later days except for a small carry-over allowance. ${ }^{2}$ Thus, deviations in supply from the quantity demanded on these days appear to have the largest impact on the funds rate. Taken at face value, it would appear that a change of a billion dollars in reserve balances is sufficient to move the funds rate by almost 3-1/2 basis points on settlement Wednesday.

\footnotetext{
${ }^{2}$ The reserve carry-over privilege provides a depository institution with some flexibility in meeting its total balance requirement. This privilege allows an institution with a small excess or deficiency (maximum carry-over allowance is the greater of four percent or $\$ 50,000$ ) in one maintenance period to use it or make it up in the following maintenance period.
} 
In contrast to Hamilton's findings, with the exception of three days - the first two days of the maintenance period and the second Friday — each day of the maintenance period displays a statistically and economically significant liquidity effect for the full sample. The penultimate day of the maintenance period and both Mondays (days 3 and 8) have the next largest point estimates, however, several of the other coefficients imply a non-trivial response of the funds rate to changes in the supply of reserve balances. Averaging coefficients across days of the maintenance period suggest that a change of $\$ 1$ billion in reserve balances could move the funds rate by about 1 basis point.

The first day of the maintenance period does not display a significant liquidity effect. Recalling a bank's demand for reserve balances (Figure 2), this may be expected. In the beginning of a maintenance period, a bank has a relatively long horizon to adjust its maintenance period average reserve balances to fulfill its requirements. Thus, the slope of the demand curve is steepest on Thursday, and changes in reserve balances elicit less of a funds rate reaction as banks are more able to intertemporally shift reserve needs. As the maintenance period progresses, this ability is diminished and thus the liquidity effect is stronger later in the maintenance period. Of curiosity, however, is the large estimated coefficient on the first Monday of the maintenance period. While this day ought to have almost as little sensitivity as the two previous days, recall that Friday balances are counted three times. As a result, although demand for reserves on the first Friday of a maintenance period may not be especially sensitive, on the subsequent Monday, once the reserve position for the previous Friday has been realized, banks may attempt to unwind some of the three-day effect from the weekend. 
The columns 5 to 7 of Table 1 presents the regression results using data since 1994, the year the Fed began announcing changes to the target rate. The results are qualitatively similar to Hamilton (1997) and our results over the longer sample. The liquidity effect on settlement Wednesday appears to be a bit smaller than the full-sample results, but most other coefficients are perhaps a touch larger, and all but one of the days of the maintenance period exhibit a statistically and economically significant liquidity effect. Thornton suggested that so-called open mouth operations may be an explanation for his not finding a liquidity effect. The logic is that the Fed is able to control the funds rate near the target rate simply by announcing the target and thus the supply of reserve balances is incidental to the funds rate. We disagree with this logic and our results do not support Thornton's conclusions. We believe that the announcement effect associated with open mouth operations is significant in changing the funds rate following a target change, as shown by the insignificant liquidity effect associated with factors misses on the day after a target change. However, the "announcement effect" only operates on the day after a target change and on the remainder of the days in our sample, maintenance of the target does require careful reserve management through open market operations. It should also be noted that it is the credibility of the Trading Desk in its commitment to the target rate that establishes market expectations and enables the announcement effect.

One interesting note is the estimated coefficient on the target funds rate. In both specifications, the point estimate is small and p-value ranging between .1 and .3; essentially the coefficient is zero. This implies, given our theoretical results above, that the Desk at the FRB-NY has been able to understand, on average and through time, the relationship between the demand for reserve balances and the federal funds rate. There is 
no evidence of systematic mis-estimation of the elasticity. Meanwhile, the coefficients associated with the set of variables that represent demand for balances are mostly significant, suggesting that the Desk does not completely offset these daily fluctuations in demand.

Finally, the positive and significant coefficient $\psi$ in the conditional variance equation indicates that the volatility effects of upward and downward moves in the funds rate are asymmetric, consistent with Hamilton (1996). An upward funds rate shock leads to greater volatility in the funds market than a downwards shock. Most of the other coefficients in the variance equation are significant and positive, except for the first Friday of a maintenance period when the volatility tends to be lower, likely due to a lower volume of trading. This finding is somewhat different from Spindt and Hoffmeister (1988) who find that the variance of the funds rate increases on both Fridays and especially on the second Friday. This result likely reflects a change in trading patterns since the period between 1984-1986, when the above results were obtained.

V-2. Non-linear liquidity effect

We next ask whether the liquidity effect that we identified above is linear in the miss. Specifically, we define a miss of $\$ 1$ billion or more to be a large miss and test whether the coefficient on large misses is the same as the coefficient on small misses. ${ }^{3}$ Our sample consists of roughly $1 / 3$ large misses and $2 / 3$ small misses, implying that we have sufficient power to test our hypothesis. The results are presented in Table 2 with

\footnotetext{
${ }^{3}$ The sample standard deviation of the forecast misses is $\$ 1.1$ billion, providing a less-arbitrary justification for our choice of large versus small.
} 
results for the post-1994 sample in the right column for comparison. These results suggest that the liquidity effect at the daily frequency is non-linear. The coefficients on small misses are statistically insignificantly different from zero for most days while the coefficients on large misses are generally larger than our results presented in Table 1. From these results, we conclude that the federal funds market is insensitive to small deviations from equilibrium. Put in slightly different terms, the demand curve for funds appears to be kinked, and roughly flat in the neighborhood of the target rate. One interpretation for this result is that the loss to a bank of a small deviation from its optimal choice for reserves on a given day is smaller than the transactions costs required to adjust its balances. This situation is reinforced by the fact that funds held to satisfy reserve requirements across different days of the maintenance period are perfectly substitutable. This result further helps to reconcile our findings with those of Hamilton and Thornton. Thornton asserts that Hamilton's results rely entirely on a handful of outliers. Our data allow us to identify a differential effect of a small miss from a large miss, suggesting that these outliers are, in fact, driving Hamilton's results, but that the imprecision in his instrument obscures the more general liquidity effect.

$\mathrm{V}-3$. The effect of the level of operating balances

Next, we ask whether the level of operating balances in the banking system is related to the size of the liquidity effect. Clouse and Elmendorf (1997) argue that for sufficiently low levels of operating balances, the federal funds market can become volatile. This concern was particularly acute as declines in required reserve ratios and the increased use of retail sweep activity dramatically lowered required reserves to a point where many banks were able to satisfy reserve requirements with vault cash. In the 
context of the liquidity effect, we would suspect that a steeper demand curve for funds would result in a more volatile funds market. In other words, if the federal funds rate is more sensitive to changes in the quantity of reserves, a given miss in the supply of reserve balances would result in a larger deviation of the funds rate from the target.

To test this hypothesis, we interact the daily forecast miss with a measure of the aggregate level of required operating balances. We take the sum of required reserve balances and contractual clearing balances, subtract the sample mean and then divide by the sample standard deviation, normalizing the level of required operating balances to a variable with a mean of zero and a standard deviation of unity.

The results are presented in Table 3, again with the post-1994 sample in the right column. We find that a higher level of required operating balances tends to attenuate the intra-maintenance period liquidity effect while it augments the end-of-maintenance period liquidity effect. In essence, a higher level of required balances allows banks to smooth deviations from their optimal choice of reserves across days of the maintenance period more easily. However, at the end of the maintenance period, the need to fulfill a higher requirement causes the funds rate to become more sensitive to deviations in supply.

A specification that includes both the differentiation between large and small misses, as well as interacting the results with the level of required operating balances is consistent with the discussion above and suggests that the two phenomena we document are independent effects. 


\section{Conclusions}

The results presented above are fairly strong evidence of a liquidity effect at the daily frequency. Hamilton's work on the daily liquidity effect is broadly consistent with these results, however, his results suggest a statistically significant liquidity effect only on the last day of the maintenance period. Our results differ from Hamilton's in a number of ways. It seems plausible that part of the difference between our results and his is the difference in our measure of exogenous changes in the supply of reserves. Hamilton created a forecast of only one factor affecting the supply of reserves and compared it to the realized level of that factor. While in principle, the logic behind this identification is sound, it seems likely that there is a great deal of estimation error and imprecision in the method. Instead, we use the errors from the forecasts of all the factors affecting the supply of reserves made by Federal Reserve in the actual conduct of monetary policy. As a result, and given the theoretical and empirical results, our approach provides a much cleaner and direct measure of exogenous changes to the supply of reserve balances and likely explains some of the difference in the results.

In addition, the liquidity effect that Hamilton estimates is significantly larger than ours. Indeed, he estimates that a change in reserve balances of $\$ 1$ billion results in a change in the funds rate of more than 22 basis points. For strictly day-to-day fluctuations, this elasticity seems very large by recent standards. Over our sample period, the deviation of the federal funds rate from the target has been approximately $3 \frac{1 / 2}{2}$ basis points. Such small deviations suggest that the funds rate is no longer so sensitive to small variations in reserve balances, a notion borne out by our examination of small versus large misses. 
Another major difference is the fact that we are able to estimate a statistically significant liquidity effect on most days of the maintenance period. Lastly, Hamilton estimates his model over a relatively short sample, from 1989 to 1991. Our sample includes this period, but is longer and more recent and consequently, we feel that our results are more representative of the current working of the market. Moreover, we document that the liquidity effect tends to be larger at the end of the maintenance period when required operating balances are higher. Recalling Exhibit 1, Hamilton's sample period is a period of extremely high operating balances. Our results would predict a smaller liquidity effect early in the maintenance period and a larger effect later in the period, suggesting that our results and Hamilton's are not dramatically at odds.

The results of our paper, however, are quite different from those of Thornton. He states

"[t]he demand for excess reserves is not well defined within the maintenance period because banks are free to alter their reserve holdings within the maintenance period so long as they hold enough reserves on a daily average basis to meet their requirement. Excess reserves become increasingly meaningful as the maintenance period draws to a close ... even if the concept of the daily demand for excess reserves were meaningful, day-to-day fluctuations in excess reserves would likely be unpredictable."

While Thornton's point is valid, it nevertheless appears that there is a systematic pattern of excess reserve balances within maintenance periods. Accordingly, our results suggest that the sensitivity of reserve balances to changes in the interest rates does increase through the maintenance period, though perhaps not strictly monotonically.

Thornton's work is in line with some of the previous work on the liquidity effect because, as he states, "the liquidity effect depends on the demand for money and not banks' demand for excess reserves." Unfortunately, this logic implies a bit of the 
mismatch we discussed in the second section of the paper. If money, e.g. demand deposits, is not tightly linked to the federal funds rate, there is no reason to suspect that a liquidity effect would be present there. However, as we discussed in the theoretical section and as our empirical results confirm, there is a relationship between overall reserve balances and the funds rate.

Furthermore, we find that the liquidity effect is non-linear. Specifically, small deviations from the target supply of reserves in the banking system do not appear to have a significant effect on the federal funds rate whereas large deviations do. This fact, combined with Hamilton's use of a noisy measure of supply shocks, reconciles our work with previous work in the literature. Finally, we also find evidence that a higher level of reserve balances in the banking system is related to a smaller liquidity effect during the maintenance period, but an elevated liquidity effect at the end of the maintenance period.

In summary, our results provide solid evidence of a liquidity effect at the daily frequency. We believe our data and methodology are more precise than Hamilton's seminal work. As a result, our results are broadly consistent with his work, but are somewhat stronger. 


\section{References}

Bernanke, B. and I. Mihov (1998), "The Liquidity Effect and Long-run Neutrality," Carnegie-Rochester Conference Series on Public Policy, 49 pp. 149-194.

Bernanke, B. and I. Mihov (1998), "Measuring Monetary Policy,” Quarterly Journal of Economics, 113, pp. 869-902.

Carpenter, S. and S. Demiralp (2003), "The Liquidity Effect in the Federal Funds Market: Evidence at the Monthly Frequency," unpublished manuscript Board of Governors of the Federal Reserve.

Christiano, L. (1991), "Modeling the Liquidity Effect of a Money Shock,” Federal Reserve Bank of Minneapolis Quarterly Review, Winter.

Clouse, J., and D. Elmendorf (1997), "Declining Required Reserves and the Volatility of the Federal Funds Rate," Finance and Economics Discussion Series 1997-30, Board of Governors of the Federal Reserve System.

Cochrane, J. (1989), "The Return of the Liquidity Effect: A Study of the Short-Run Relation Between Money Growth and Interest Rates," Journal of Business and Economics Statistics, 7, pp. 75-83.

Demiralp, S. and D. Farley (2004), "Declining Required Reserves, Funds Rate Volatility, and Open Market Operations," Journal of Banking and Finance, (forthcoming).

Gali, J. (1992), "How Well does the IS-LM Model Fit Postwar US Data?" Quarterly Journal of Economics, 107, pp. 709-738.

Hamilton, James (1996.) The Daily Market for Federal Funds. Journal of Political Economy 104: 26-56.

Hamilton, J. (1997), "Measuring the Liquidity Effect," American Economic Review, March, 87(1), pp. 80-97.

Leeper, E. and R. Gordon (1992), "In Search of the Liquidity Effect," Journal of Monetary Economics, 29, pp. 341-369.

Nelson, Daniel (1991.) Conditional Heteroskedasticity in Asset Returns: A New Approach," Econometrica 59: 347-370.

Pagan, A. and J. Robertson, (1995), "Resolving the Liquidity Effect," Federal Reserve Bank of St. Louis Review, 77, pp. 33-54.

Reichenstein, W (1987), "The impact of money on short term interest rates," Economic Inquiry XXV, pp. 67-82. 
Spindt, Paul and J. Hoffmeister (1988.) The Micromechanics of the Federal Funds Market: Implications of day-of-the-week Effects in Funds Rate Volatility. Journal of Financial and Quantitative Analysis 23 (4): 401-416

Strongin, S. (1995), “The Identification of Monetary Policy Disturbances: Explaining the Liquidity Puzzle.” Journal of Monetary Economics, August, 35(5), pp. 463-397.

Thornton, D. (2001), "Identifying the Liquidity Effect at the Daily Frequency" Federal Reserve Bank of St. Louis Review, July/August, pp. 59-78. 
Table 1

Dependent Variable: (Deviation From Target) ${ }_{t}$

Sample Period: $\quad$ May 18, 1989-Jan 30, 2004

\begin{tabular}{|c|c|c|c|c|c|c|}
\hline \multirow[b]{2}{*}{ Variable } & \multicolumn{3}{|c|}{ Full Sample } & \multicolumn{3}{|c|}{ Post-94 } \\
\hline & Coeff. & Std. Err. & Prob. & Coeff. & Std. Err. & Prob. \\
\hline (Deviation from Target $)_{t-1} \times D_{\text {Week } 1}$ & 0.29 & 0.01 & 0.00 & 0.28 & 0.02 & 0.00 \\
\hline$(\text { Deviation from Target })_{t-1} \times D_{\text {Week } 2}$ & 0.45 & 0.02 & 0.00 & 0.38 & 0.03 & 0.00 \\
\hline$($ Forecast Miss $) \times D_{\text {First Thursday }}$ & -0.58 & 0.85 & 0.50 & -0.75 & 0.90 & 0.40 \\
\hline$($ Forecast Miss $) \times D_{\text {First Friday }}$ & 0.06 & 0.17 & 0.74 & -0.62 & 0.30 & 0.04 \\
\hline$($ Forecast Miss $) \times D_{\text {First Monday }}$ & -1.34 & 0.16 & 0.00 & -2.57 & 0.19 & 0.00 \\
\hline$($ Forecast Miss $) \times D_{\text {First Tuesday }}$ & -0.64 & 0.17 & 0.00 & -0.62 & 0.21 & 0.00 \\
\hline$($ Forecast Miss $) \times D_{\text {FirstWednesday }}$ & -0.70 & 0.22 & 0.00 & -0.99 & 0.29 & 0.00 \\
\hline$($ Forecast Miss $) \times D_{\text {Second Thursday }}$ & -0.49 & 0.26 & 0.06 & -0.58 & 0.32 & 0.07 \\
\hline$($ Forecast Miss $) \times D_{\text {Second Friday }}$ & -0.25 & 0.40 & 0.54 & -0.25 & 0.46 & 0.60 \\
\hline$($ Forecast Miss $) \times D_{\text {Second Monday }}$ & -1.33 & 0.59 & 0.02 & -1.25 & 0.71 & 0.08 \\
\hline$($ Forecast Miss $) \times D_{\text {Second Tuesday }}$ & -1.08 & 0.47 & 0.02 & -0.75 & 0.44 & 0.09 \\
\hline$($ Forecast Miss $) \times D_{\text {Second Wednesday }}$ & -3.41 & 0.67 & 0.00 & -1.93 & 0.90 & 0.03 \\
\hline$($ Forecast Miss $) \times D_{\text {Day after a Target Change }}$ & -0.13 & 1.83 & 0.94 & 1.12 & 2.97 & 0.71 \\
\hline$D_{\text {First Thursday }}$ & 2.17 & 0.79 & 0.01 & 2.24 & 0.94 & 0.02 \\
\hline$D_{\text {First Friday }}$ & -5.16 & 0.41 & 0.00 & -4.32 & 0.56 & 0.00 \\
\hline$D_{\text {First Monday }}$ & 4.04 & 0.34 & 0.00 & 2.63 & 0.55 & 0.00 \\
\hline$D_{\text {First Tuesday }}$ & -2.01 & 0.41 & 0.00 & -2.74 & 0.58 & 0.00 \\
\hline$D_{\text {FirstWednesday }}$ & -1.70 & 0.42 & 0.00 & -1.13 & 0.55 & 0.04 \\
\hline$D_{\text {Second Thursday }}$ & 1.67 & 0.42 & 0.00 & 2.18 & 0.56 & 0.00 \\
\hline$D_{\text {Second Friday }}$ & -4.05 & 0.45 & 0.00 & -3.06 & 0.59 & 0.00 \\
\hline$D_{\text {Second Monday }}$ & 4.54 & 0.92 & 0.00 & 3.83 & 1.05 & 0.00 \\
\hline$D_{\text {Second Tuesday }}$ & -6.75 & 0.91 & 0.00 & -7.50 & 1.09 & 0.00 \\
\hline$D_{\text {Second Wednesday }}$ & 8.58 & 1.02 & 0.00 & 5.03 & 1.03 & 0.00 \\
\hline$D_{\text {Month End }}$ & 12.86 & 1.52 & 0.00 & 13.06 & 1.57 & 0.00 \\
\hline$D_{\text {Month Start }}$ & 5.73 & 0.98 & 0.00 & 6.42 & 1.08 & 0.00 \\
\hline$D_{\text {Quarter End }}$ & 50.13 & 3.81 & 0.00 & 55.65 & 5.84 & 0.00 \\
\hline$D_{\text {Quarter Start }}$ & 6.79 & 2.86 & 0.02 & 11.33 & 3.71 & 0.00 \\
\hline$D_{\text {Year End }}$ & -27.12 & 2.88 & 0.00 & -39.06 & 4.08 & 0.00 \\
\hline
\end{tabular}


Table 1, Continued.

\begin{tabular}{l|ccc|ccc}
\hline \multirow{2}{*}{\multicolumn{1}{c|}{ Variable }} & \multicolumn{3}{c}{ Full Sample } & \multicolumn{3}{c}{ Post-94 } \\
\cline { 2 - 7 } & Coeff. & Std. Err. & Prob. & Coeff. & Std. Err. & Prob. \\
\hline$D_{\text {Year Start }}$ & 17.28 & 6.88 & 0.01 & 5.76 & 6.54 & 0.38 \\
$D_{\text {Mid-Month }}$ & 10.17 & 0.34 & 0.00 & 9.21 & 0.44 & 0.00 \\
$D_{\text {Day Before Holiday }}$ & -2.57 & 1.10 & 0.02 & -1.72 & 1.37 & 0.21 \\
$D_{\text {Day After Holiday }}$ & 11.06 & 1.13 & 0.00 & 13.09 & 1.46 & 0.00 \\
$E_{t}\left(\Delta\right.$ Target $\left._{t+1}\right) \times D_{\text {Day beforea Target Change }} \times D_{\text {Week } 1}$ & 0.29 & 0.09 & 0.00 & 0.26 & 0.08 & 0.00 \\
$E_{t}\left(\Delta\right.$ Target $\left._{t+1}\right) \times D_{\text {Daybeforea TargetChange }} \times D_{\text {Week } 2}$ & 0.14 & 0.15 & 0.36 & 0.23 & 0.21 & 0.29 \\
$\left(\right.$ Unanti $\left._{t}\right) \times D_{\text {Dayof a TargetChange }}$ & -0.63 & 0.08 & 0.00 & -0.53 & 0.17 & 0.00 \\
Target & -0.07 & 0.06 & 0.26 & -0.15 & 0.09 & 0.11 \\
December & -1.08 & 0.69 & 0.11 & -0.64 & 1.01 & 0.53 \\
\hline \hline
\end{tabular}

Variance Equation

\begin{tabular}{l|ccc|ccc}
\hline \multirow{2}{*}{ Variable } & \multicolumn{3}{c|}{ Full Sample } & \multicolumn{3}{c}{ Post-94 } \\
\cline { 2 - 7 } & Coeff. & Std. Err. & Prob. & Coeff. & Std. Err. & Prob. \\
\hline $\mathrm{C}$ & 1.05 & 0.05 & 0.00 & 1.25 & 0.07 & 0.00 \\
$|\mathrm{RES}| \mathrm{SQR}[\mathrm{GARCH}](1)$ & 0.58 & 0.02 & 0.00 & 0.51 & 0.03 & 0.00 \\
$\mathrm{RES} / \mathrm{SQR}[\mathrm{GARCH}(1)$ & 0.04 & 0.02 & 0.03 & 0.06 & 0.02 & 0.01 \\
EGARCH(1) & 0.55 & 0.01 & 0.00 & 0.51 & 0.02 & 0.00 \\
$D_{\text {Last three daysof Maintenance Period }}$ & 1.43 & 0.04 & 0.00 & 1.18 & 0.05 & 0.00 \\
First Friday & -0.41 & 0.08 & 0.00 & -0.52 & 0.09 & 0.00 \\
Second Friday & 0.19 & 0.05 & 0.00 & 0.11 & 0.06 & 0.05 \\
$D_{\text {Day beforea TargetChange }}$ & 0.89 & 0.12 & 0.00 & 0.57 & 0.25 & 0.02 \\
$D_{\text {Day aftera TargetChange }}$ & 0.22 & 0.14 & 0.11 & 0.21 & 0.21 & 0.31 \\
$D_{\text {Day of Target Change }}$ & 0.47 & 0.16 & 0.00 & 0.93 & 0.31 & 0.00 \\
$D_{\text {Day After Holiday }}$ & 0.81 & 0.08 & 0.00 & 0.94 & 0.11 & 0.00 \\
$D_{\text {Day Before Holiday }}$ & 1.45 & 0.08 & 0.00 & 1.44 & 0.11 & 0.00 \\
$D_{\text {Quarter End }}$ & 3.60 & 0.15 & 0.00 & 4.00 & 0.22 & 0.00 \\
December & 0.37 & 0.04 & 0.00 & 0.51 & 0.05 & 0.00 \\
$D_{\text {Month End }}$ & 1.44 & 0.10 & 0.00 & 1.27 & 0.11 & 0.00 \\
\hline \hline
\end{tabular}


Table 2

Dependent Variable: (Deviation From Target) ${ }_{t}$

Sample Period:

May 18, 1989-Jan 30, 2004

\begin{tabular}{|c|c|c|c|c|c|c|}
\hline \multirow[b]{2}{*}{ Variable } & \multicolumn{3}{|c|}{ Full Sample } & \multicolumn{3}{|c|}{ Post 94} \\
\hline & Coeff. & Std. Err. & Prob. & Coeff. & Std. Err. & Prob. \\
\hline (Deviation from Target $)_{t-1} \times D_{\text {Week } 1}$ & 0.30 & 0.01 & 0.00 & 0.27 & 0.02 & 0.00 \\
\hline$(\text { Deviation from Target })_{t-1} \times D_{\text {Week } 2}$ & 0.45 & 0.02 & 0.00 & 0.38 & 0.03 & 0.00 \\
\hline$($ Forecast Miss $) \times D_{\text {First Thursday }} \times D_{\text {Large Miss }}$ & -0.95 & 1.00 & 0.34 & -1.10 & 0.95 & 0.25 \\
\hline$($ Forecast Miss $) \times D_{\text {First Friday }} \times D_{\text {Large Miss }}$ & -1.61 & 0.24 & 0.00 & -1.24 & 0.47 & 0.01 \\
\hline$($ Forecast Miss $) \times D_{\text {First Monday }} \times D_{\text {Large Miss }}$ & -1.36 & 0.18 & 0.00 & -2.42 & 0.19 & 0.00 \\
\hline$($ Forecast Miss $) \times D_{\text {First Tuesday }} \times D_{\text {Large Miss }}$ & -0.68 & 0.18 & 0.00 & -0.84 & 0.23 & 0.00 \\
\hline$($ Forecast Miss $) \times D_{\text {FirstWednesday }} \times D_{\text {Large Miss }}$ & -0.88 & 0.24 & 0.00 & -1.08 & 0.31 & 0.00 \\
\hline$($ Forecast Miss $) \times D_{\text {Second Thursday }} \times D_{\text {Large Miss }}$ & -0.80 & 0.28 & 0.00 & -0.77 & 0.34 & 0.02 \\
\hline$($ Forecast Miss $) \times D_{\text {Second Friday }} \times D_{\text {Large Miss }}$ & -0.11 & 0.46 & 0.82 & -0.35 & 0.53 & 0.51 \\
\hline$($ Forecast Miss $) \times D_{\text {Second Monday }} \times D_{\text {Large Miss }}$ & -1.35 & 0.62 & 0.03 & -1.54 & 0.80 & 0.05 \\
\hline$($ Forecast Miss $) \times D_{\text {Second Tuesday }} \times D_{\text {Large Miss }}$ & -1.17 & 0.50 & 0.02 & -0.22 & 0.42 & 0.59 \\
\hline$($ Forecast Miss $) \times D_{\text {Second Wednesday }} \times D_{\text {Large Miss }}$ & -3.86 & 0.72 & 0.00 & -2.40 & 1.04 & 0.02 \\
\hline$($ Forecast Miss $) \times D_{\text {First Thursday }} \times D_{\text {Small Miss }}$ & 0.90 & 1.63 & 0.58 & 0.93 & 1.97 & 0.64 \\
\hline$($ Forecast Miss $) \times D_{\text {First Friday }} \times D_{\text {Small Miss }}$ & 1.27 & 0.64 & 0.05 & 1.71 & 0.62 & 0.01 \\
\hline$($ Forecast Miss $) \times D_{\text {First Monday }} \times D_{\text {Small Miss }}$ & -1.17 & 0.42 & 0.01 & -4.02 & 0.65 & 0.00 \\
\hline$($ Forecast Miss $) \times D_{\text {First Tuesday }} \times D_{\text {Small Miss }}$ & 0.69 & 0.57 & 0.23 & 1.47 & 0.73 & 0.04 \\
\hline$($ Forecast Miss $) \times D_{\text {First Wednesday }} \times D_{\text {Small Miss }}$ & -0.36 & 0.62 & 0.56 & 0.09 & 0.77 & 0.91 \\
\hline$($ Forecast Miss $) \times D_{\text {Second Thursday }} \times D_{\text {Small Miss }}$ & 1.18 & 0.58 & 0.04 & 0.94 & 0.76 & 0.21 \\
\hline$($ Forecast Miss $) \times D_{\text {Second Friday }} \times D_{\text {Small Miss }}$ & -0.51 & 0.75 & 0.49 & 0.02 & 0.89 & 0.98 \\
\hline$($ Forecast Miss $) \times D_{\text {Second Monday }} \times D_{\text {Small Miss }}$ & -1.19 & 1.71 & 0.49 & 0.04 & 1.80 & 0.98 \\
\hline$($ Forecast Miss $) \times D_{\text {Second Tuesday }} \times D_{\text {Small Miss }}$ & -0.53 & 1.81 & 0.77 & -3.43 & 1.79 & 0.06 \\
\hline$($ Forecast Miss $) \times D_{\text {Second Wednesday }} \times D_{\text {Small Miss }}$ & -0.68 & 2.08 & 0.74 & -0.83 & 1.86 & 0.66 \\
\hline$($ Forecast Miss $) \times D_{\text {Dayafter Target Change }} \times D_{\text {Large Miss }}$ & 0.78 & 2.29 & 0.73 & 2.85 & 4.51 & 0.53 \\
\hline$($ Forecast Miss $) \times D_{\text {Day after Target Change }} \times D_{\text {Small Miss }}$ & -4.66 & 3.27 & 0.15 & -3.25 & 5.68 & 0.57 \\
\hline$D_{\text {First Thursday }}$ & 2.12 & 0.81 & 0.01 & 2.22 & 0.92 & 0.02 \\
\hline$D_{\text {First Friday }}$ & -4.51 & 0.40 & 0.00 & -4.15 & 0.51 & 0.00 \\
\hline$D_{\text {First Monday }}$ & 4.08 & 0.38 & 0.00 & 2.55 & 0.51 & 0.00 \\
\hline$D_{\text {First Tuesday }}$ & -2.26 & 0.40 & 0.00 & -2.52 & 0.56 & 0.00 \\
\hline
\end{tabular}




\begin{tabular}{|c|c|c|c|c|c|c|}
\hline \multirow[b]{2}{*}{ Variable } & \multicolumn{3}{|c|}{ Full Sample } & \multicolumn{3}{|c|}{ Post 94} \\
\hline & Coeff. & Std. Err. & Prob. & Coeff. & Std. Err. & Prob. \\
\hline$D_{\text {FirstWednesday }}$ & -1.68 & 0.41 & 0.00 & -1.11 & 0.53 & 0.03 \\
\hline$D_{\text {Second Thursday }}$ & 1.89 & 0.42 & 0.00 & 2.37 & 0.52 & 0.00 \\
\hline$D_{\text {Second Friday }}$ & -3.84 & 0.45 & 0.00 & -2.90 & 0.55 & 0.00 \\
\hline$D_{\text {Second Monday }}$ & 4.61 & 0.93 & 0.00 & 3.62 & 1.04 & 0.00 \\
\hline$D_{\text {Second Tuesday }}$ & -6.61 & 0.94 & 0.00 & -7.59 & 1.01 & 0.00 \\
\hline$D_{\text {Second Wednesday }}$ & 8.85 & 1.04 & 0.00 & 4.96 & 1.02 & 0.00 \\
\hline$D_{\text {Month End }}$ & 12.55 & 1.54 & 0.00 & 12.94 & 1.56 & 0.00 \\
\hline$D_{\text {Month Start }}$ & 5.39 & 0.99 & 0.00 & 6.60 & 1.05 & 0.00 \\
\hline$D_{\text {Quarter End }}$ & 49.54 & 3.56 & 0.00 & 56.22 & 4.97 & 0.00 \\
\hline$D_{\text {Quarter Start }}$ & 6.04 & 2.82 & 0.03 & 11.46 & 3.24 & 0.00 \\
\hline$D_{\text {Year End }}$ & -26.15 & 2.84 & 0.00 & -40.87 & 4.00 & 0.00 \\
\hline$D_{\text {Year Start }}$ & 17.45 & 7.01 & 0.01 & 7.02 & 6.22 & 0.26 \\
\hline$D_{\text {Mid-Month }}$ & 10.29 & 0.36 & 0.00 & 9.19 & 0.47 & 0.00 \\
\hline$D_{\text {Day Before Holiday }}$ & -3.05 & 1.11 & 0.01 & -1.71 & 1.34 & 0.20 \\
\hline$D_{\text {Day Affer Holiday }}$ & 11.15 & 1.13 & 0.00 & 13.08 & 1.43 & 0.00 \\
\hline$E_{t}\left(\Delta\right.$ Target $\left._{t+1}\right) \times D_{\text {Day beforea Target Change }} \times D_{\text {Week } 1}$ & 0.30 & 0.09 & 0.00 & 0.27 & 0.08 & 0.00 \\
\hline$E_{t}\left(\Delta\right.$ Target $\left._{t+1}\right) \times D_{\text {Day beforea Target Change }} \times D_{\text {Week } 2}$ & 0.14 & 0.14 & 0.34 & 0.23 & 0.20 & 0.25 \\
\hline$\left(\right.$ Unanti $\left._{t}\right) \times D_{\text {Day of a Target Change }}$ & -0.61 & 0.09 & 0.00 & -0.49 & 0.17 & 0.00 \\
\hline Target & -0.10 & 0.07 & 0.12 & -0.18 & 0.09 & 0.04 \\
\hline December & -1.48 & 0.71 & 0.04 & -0.67 & 0.96 & 0.48 \\
\hline
\end{tabular}

Variance Equation

\begin{tabular}{l|rrr|rcc}
\hline \multirow{2}{*}{ Variable } & \multicolumn{3}{c|}{ Full Sample } & \multicolumn{3}{c}{ Post 94 } \\
\cline { 2 - 7 } C & Coeff. & Std. Err. Prob. & Coeff. & Std. Err. & Prob. \\
\hline RES|SQR[GARCH](1) & 1.04 & 0.05 & 0.00 & 1.28 & 0.08 & 0.00 \\
RES/SQR[GARCH](1) & 0.60 & 0.03 & 0.00 & 0.59 & 0.04 & 0.00 \\
EGARCH(1) & 0.03 & 0.02 & 0.11 & 0.07 & 0.02 & 0.00 \\
$D_{\text {Last threedaysof Maintenance Period }}$ & 0.55 & 0.01 & 0.00 & 0.48 & 0.02 & 0.00 \\
First Friday & 1.43 & 0.04 & 0.00 & 1.21 & 0.05 & 0.00 \\
Second Friday & -0.44 & 0.08 & 0.00 & -0.53 & 0.10 & 0.00 \\
\hline
\end{tabular}


Table 2, Continued

\begin{tabular}{l|ccc|ccc}
\hline & \multicolumn{3}{|c|}{ Full Sample } & \multicolumn{4}{c}{ Post 94 } \\
& Variable & Coeff. & Std. Err. Prob. & Coeff. & Std. Err. Prob. \\
\hline$D_{\text {Day beforea Target Change }}$ & 0.89 & 0.12 & 0.00 & 0.52 & 0.25 & 0.04 \\
$D_{\text {Day after a TargetChange }}$ & 0.20 & 0.15 & 0.16 & 0.25 & 0.22 & 0.25 \\
$D_{\text {Day of a Target Change }}$ & 0.50 & 0.16 & 0.00 & 1.00 & 0.32 & 0.00 \\
$D_{\text {Day After Holiday }}$ & 0.81 & 0.08 & 0.00 & 0.99 & 0.11 & 0.00 \\
$D_{\text {Day Before Holiday }}$ & 1.46 & 0.08 & 0.00 & 1.46 & 0.11 & 0.00 \\
$D_{\text {Quarter End }}$ & 3.59 & 0.14 & 0.00 & 3.80 & 0.19 & 0.00 \\
December & 0.38 & 0.04 & 0.00 & 0.56 & 0.05 & 0.00 \\
$D_{\text {Month End }}$ & 1.47 & 0.10 & 0.00 & 1.31 & 0.12 & 0.00 \\
\hline \hline
\end{tabular}


Table 3

Dependent Variable: (Deviation From Target) ${ }_{t}$

Sample Period: $\quad$ May 18, 1989-Jan 30, 2004

\begin{tabular}{|c|c|c|c|c|c|c|}
\hline \multirow[b]{2}{*}{ Variable } & \multicolumn{3}{|c|}{ Full Sample } & \multicolumn{3}{|c|}{ Post-94 } \\
\hline & Coeff. & Std. Err. & Prob. & Coeff. & Std. Err. & Prob \\
\hline$(\text { Deviation from Target })_{t-1} \times D_{\text {Week } 1}$ & 0.28 & 0.01 & 0.00 & 0.28 & 0.02 & 0.00 \\
\hline$(\text { Deviation from Target })_{t-1} \times D_{\text {Week } 2}$ & 0.45 & 0.02 & 0.00 & 0.37 & 0.03 & 0.00 \\
\hline$($ Forecast Miss $) \times D_{\text {First Thursday }}$ & -0.65 & 0.80 & 0.42 & -0.67 & 1.47 & 0.65 \\
\hline$($ Forecast Miss $) \times D_{\text {First Friday }}$ & 0.48 & 0.22 & 0.03 & -0.49 & 0.66 & 0.46 \\
\hline$($ Forecast Miss $) \times D_{\text {First Monday }}$ & -1.20 & 0.18 & 0.00 & -1.77 & 0.41 & 0.00 \\
\hline$($ Forecast Miss $) \times D_{\text {First Tuesday }}$ & -0.57 & 0.21 & 0.01 & -0.57 & 0.34 & 0.09 \\
\hline$($ Forecast Miss $) \times D_{\text {FirstWednesday }}$ & -0.57 & 0.24 & 0.02 & -0.42 & 0.47 & 0.37 \\
\hline$($ Forecast Miss $) \times D_{\text {Second Thursday }}$ & -0.51 & 0.27 & 0.06 & -0.53 & 0.49 & 0.28 \\
\hline$($ Forecast Miss $) \times D_{\text {Second Friday }}$ & -0.27 & 0.42 & 0.52 & -0.34 & 0.49 & 0.49 \\
\hline$($ Forecast Miss $) \times D_{\text {Second Monday }}$ & -0.73 & 0.69 & 0.29 & -0.92 & 1.32 & 0.48 \\
\hline$($ Forecast Miss $) \times D_{\text {Second Tuesday }}$ & -4.11 & 0.61 & 0.00 & -3.81 & 0.65 & 0.00 \\
\hline$($ Forecast Miss $) \times D_{\text {Second Wednesday }}$ & -4.13 & 0.83 & 0.00 & -3.43 & 0.98 & 0.00 \\
\hline$($ Forecast Miss $) \times D_{\text {First Thursday }} \times(R O B) *$ & -0.04 & 0.82 & 0.96 & 0.19 & 1.40 & 0.89 \\
\hline$($ Forecast Miss $) \times D_{\text {First Friday }} \times($ ROB $)$ & 1.03 & 0.20 & 0.00 & 0.17 & 0.58 & 0.77 \\
\hline$($ Forecast Miss $) \times D_{\text {First Monday }} \times($ ROB $)$ & 0.14 & 0.19 & 0.47 & 1.34 & 0.45 & 0.00 \\
\hline$($ Forecast Miss $) \times D_{\text {First Tuesday }} \times($ ROB $)$ & 0.55 & 0.27 & 0.04 & 0.24 & 0.44 & 0.58 \\
\hline$($ Forecast Miss $) \times D_{\text {FirstWednesday }} \times($ ROB $)$ & 0.58 & 0.25 & 0.02 & 0.92 & 0.51 & 0.07 \\
\hline$($ Forecast Miss $) \times D_{\text {Second Thursday }} \times($ ROB $)$ & 0.23 & 0.26 & 0.38 & 0.15 & 0.48 & 0.75 \\
\hline$($ Forecast Miss $) \times D_{\text {Second Friday }} \times(R O B)$ & -0.25 & 0.47 & 0.60 & -0.48 & 0.61 & 0.43 \\
\hline$($ Forecast Miss $) \times D_{\text {Second Monday }} \times($ ROB $)$ & 0.88 & 0.70 & 0.21 & 0.20 & 1.45 & 0.89 \\
\hline$($ Forecast Miss $) \times D_{\text {Second Tuesday }} \times(R O B)$ & -3.39 & 0.51 & 0.00 & -2.46 & 1.14 & 0.03 \\
\hline$($ Forecast Miss $) \times D_{\text {Second Wednesday }} \times(R O B)$ & -2.55 & 0.82 & 0.00 & -2.68 & 1.20 & 0.03 \\
\hline
\end{tabular}

*ROB is the normalized value of Required Operating Balances. 


\begin{tabular}{|c|c|c|c|c|c|c|}
\hline$($ Forecast Miss $) \times D_{\text {Day after a Target Change }}$ & 0.84 & 2.44 & 0.73 & 0.90 & 3.49 & 0.80 \\
\hline$($ Forecast Miss $) \times D_{\text {Day after a Target Change }} \times(R O B)$ & -1.27 & 2.10 & 0.55 & -1.17 & 2.81 & 0.68 \\
\hline$D_{\text {First Thursday }}$ & 2.03 & 0.81 & 0.01 & 2.32 & 0.94 & 0.01 \\
\hline$D_{\text {First Friday }}$ & -5.02 & 0.40 & 0.00 & -4.22 & 0.57 & 0.00 \\
\hline$D_{\text {First Monday }}$ & 4.01 & 0.32 & 0.00 & 2.64 & 0.56 & 0.00 \\
\hline$D_{\text {First Tuesday }}$ & -2.06 & 0.40 & 0.00 & -2.68 & 0.59 & 0.00 \\
\hline$D_{\text {FirstWednesday }}$ & -1.85 & 0.41 & 0.00 & -1.17 & 0.56 & 0.04 \\
\hline$D_{\text {Second Thursday }}$ & 1.63 & 0.40 & 0.00 & 2.20 & 0.58 & 0.00 \\
\hline$D_{\text {Second Friday }}$ & -4.07 & 0.44 & 0.00 & -2.98 & 0.61 & 0.00 \\
\hline$D_{\text {Second Monday }}$ & 4.20 & 0.85 & 0.00 & 3.89 & 1.12 & 0.00 \\
\hline$D_{\text {Second Tuesday }}$ & -5.50 & 0.76 & 0.00 & -5.92 & 0.93 & 0.00 \\
\hline$D_{\text {Second Wednesday }}$ & 8.13 & 0.97 & 0.00 & 5.24 & 1.03 & 0.00 \\
\hline$D_{\text {Month End }}$ & 12.93 & 1.49 & 0.00 & 13.27 & 1.61 & 0.00 \\
\hline$D_{\text {Month Start }}$ & 5.88 & 0.95 & 0.00 & 6.47 & 1.07 & 0.00 \\
\hline$D_{\text {Quarter End }}$ & 50.65 & 3.44 & 0.00 & 55.52 & 5.73 & 0.00 \\
\hline$D_{\text {Quarter Start }}$ & 6.71 & 2.89 & 0.02 & 12.44 & 3.25 & 0.00 \\
\hline$D_{\text {Year End }}$ & -26.92 & 2.94 & 0.00 & -38.96 & 3.80 & 0.00 \\
\hline$D_{\text {Year Start }}$ & 14.82 & 6.92 & 0.03 & 1.29 & 6.22 & 0.84 \\
\hline$D_{\text {Mid-Month }}$ & 10.14 & 0.35 & 0.00 & 9.50 & 0.47 & 0.00 \\
\hline$D_{\text {Day Before Holiday }}$ & -2.40 & 1.10 & 0.03 & -1.60 & 1.46 & 0.27 \\
\hline$D_{\text {Day After Holiday }}$ & 12.22 & 1.18 & 0.00 & 13.65 & 1.60 & 0.00 \\
\hline$E_{t}\left(\Delta\right.$ Target $\left._{t+1}\right) \times D_{\text {Day beforea Target Change }} \times D_{\text {Week } 1}$ & 0.29 & 0.10 & 0.00 & 0.27 & 0.09 & 0.00 \\
\hline$E_{t}\left(\Delta\right.$ Target $\left._{t+1}\right) \times D_{\text {Daybeforea Target Change }} \times D_{\text {Week } 2}$ & 0.14 & 0.14 & 0.32 & 0.24 & 0.22 & 0.29 \\
\hline$\left(\right.$ Unanti $\left._{t}\right) \times D_{\text {Day of a Target Change }}$ & -0.64 & 0.09 & 0.00 & -0.59 & 0.16 & 0.00 \\
\hline Target & -0.07 & 0.06 & 0.28 & -0.18 & 0.10 & 0.07 \\
\hline December & -1.39 & 0.70 & 0.05 & -0.88 & 1.01 & 0.38 \\
\hline
\end{tabular}




\begin{tabular}{l|ccc|ccc}
\hline \multirow{2}{*}{ Variable } & \multicolumn{3}{c|}{ Full Sample } & \multicolumn{3}{c}{ Post-94 } \\
\cline { 2 - 7 } C Coeff. & Std. Err. & Prob. & Coeff. & Std. Err. & Prob. \\
\hline RES|/SQR[GARCH](1) & 1.00 & 0.05 & 0.00 & 1.37 & 0.07 & 0.00 \\
RES/SQR[GARCH](1) & 0.64 & 0.02 & 0.00 & 0.52 & 0.03 & 0.00 \\
EGARCH(1) & 0.02 & 0.02 & 0.32 & 0.06 & 0.02 & 0.01 \\
$D_{\text {Last threedaysof Maintenance Period }}$ & 0.55 & 0.01 & 0.00 & 0.47 & 0.02 & 0.00 \\
First Friday & 1.39 & 0.04 & 0.00 & 1.22 & 0.05 & 0.00 \\
Second Friday & -0.38 & 0.08 & 0.00 & -0.49 & 0.09 & 0.00 \\
$D_{\text {Day beforea Target Change }}$ & 0.21 & 0.05 & 0.00 & 0.12 & 0.06 & 0.04 \\
$D_{\text {Day after a TargetChange }}$ & 0.93 & 0.11 & 0.00 & 0.60 & 0.25 & 0.02 \\
$D_{\text {Day of a Target Change }}$ & 0.25 & 0.14 & 0.08 & 0.30 & 0.21 & 0.15 \\
$D_{\text {Day After Holiday }}$ & 0.53 & 0.16 & 0.00 & 0.92 & 0.30 & 0.00 \\
$D_{\text {Day Before Holiday }}$ & 0.84 & 0.09 & 0.00 & 1.03 & 0.12 & 0.00 \\
$D_{\text {Quarter End }}$ & 1.48 & 0.08 & 0.00 & 1.46 & 0.11 & 0.00 \\
$D_{\text {December }}$ & 3.54 & 0.15 & 0.00 & 3.95 & 0.22 & 0.00 \\
$D_{\text {Month End }}$ & 0.38 & 0.04 & 0.00 & 0.52 & 0.05 & 0.00 \\
\hline \hline
\end{tabular}


Exhibit 1: Reserve Balances

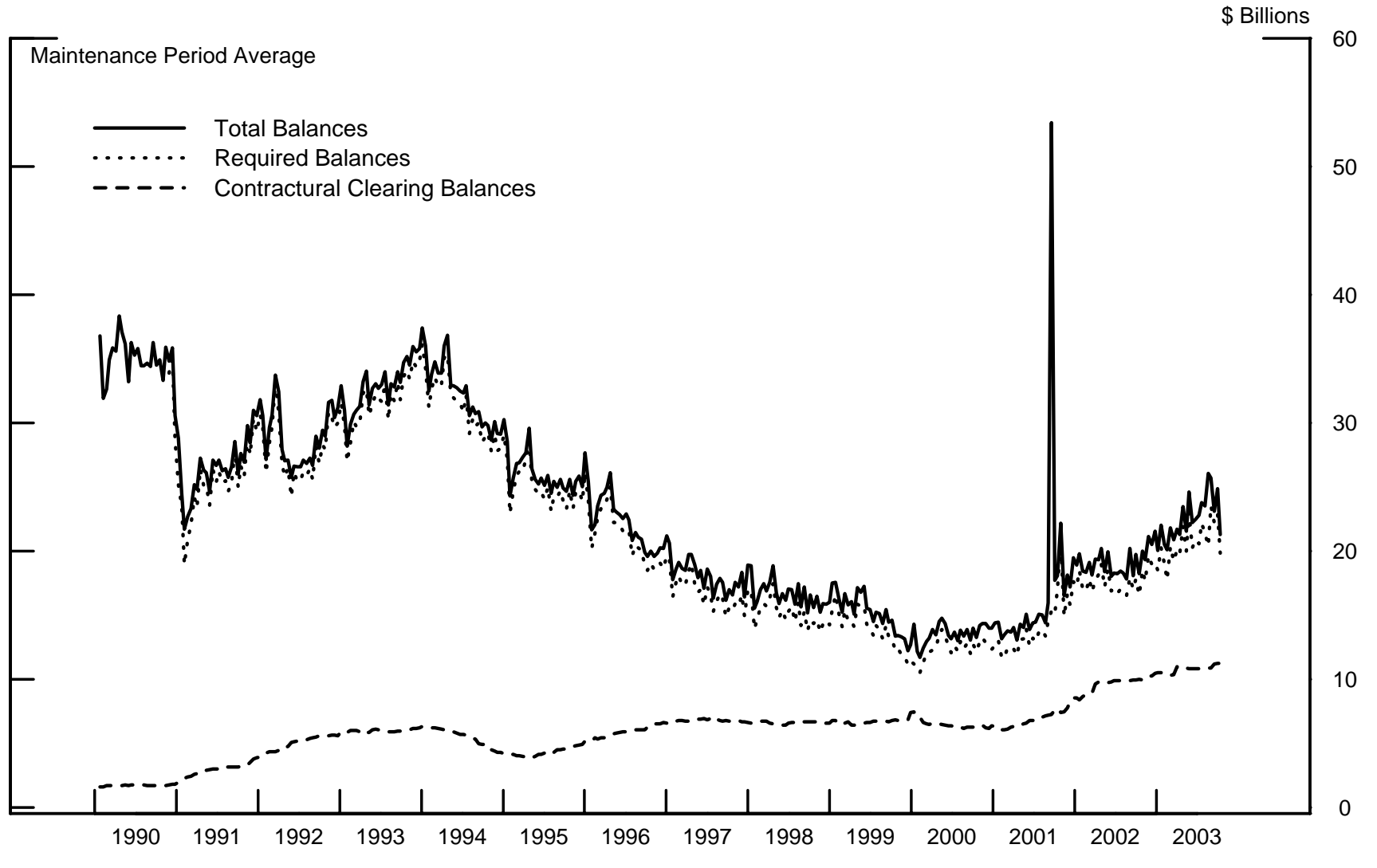

Exhibit 2: Average Daily Excess Balances (1990 - present)

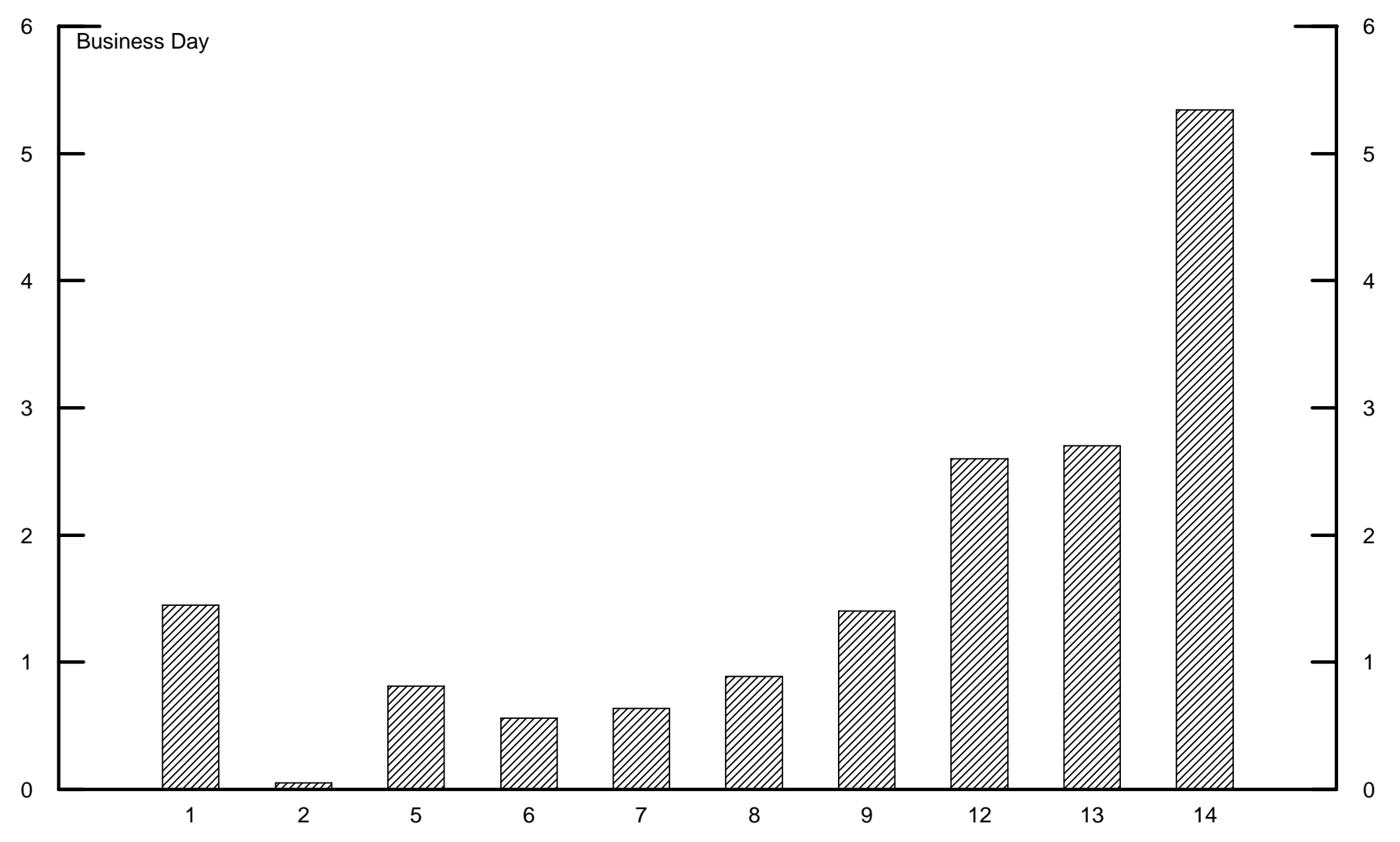

